Ковалева Н. С.

Kovaleva N. S.

\title{
CURRENT CHARACTERISTICS OF CRIME OF MINORS WOMEN IN RUSSIA
}

В условиях кризисных явлений в экономике исследуются проблемы, связанные с фактическим состоянием преступности несовершеннолетних женщин. В статье рассмотрены основные аспекты преступности несовершеннолетних женского пола в Российской Федерации: приводится динамика показателей преступности несовершеннолетних женщин за 5 лет (с 2014 по 2019 г.), анализируются количественные показатели преступлений, которые чаще всего совершают несовершеннолетние девушки,рассматриваются особенности, характеризующие подростковую женскую преступность, уделяется внимание женской рецидивной преступности.На основании анализа статистических данных выявлены особенности данного вида преступности, а также отмечена тенденция роста криминальной активности несовершеннолетних женского пола.

Ключевые слова: преступность, несовершеннолетние девушки, структура, показатели, латентность, рецидив.

In the conditions of crisis in the economy, problems related to the actual state of crime of minor women are investigated. The article considers the main aspects of juvenile delinquency in the Russian Federation: the dynamics of juvenile delinquency indicators for 5 years (from 2014 to 2019) is given, quantitative indicators of crimes that are most often committed by underage girls are analyzed, and features that characterize juvenile delinquency, attention is paid to female recidivism. Based on the analysis of statistical data, the features of this type of crime are revealed, as well as a tendency to increase the criminal activity of female minors.

Keywords: crime, minor girls, structure, indicators, latency, relapse.

Основной характеристикой личности преступника выступает его возраст. Ведь каждое преступление будет квалифицироваться по-разному в зависимости от возраста обвиняемого. Таким образом, определение возраста является первоочередным моментов при квалификации преступления.

Так, по мнению Б.Б. Казака и А.И. Ушатикова «Некоторые преступления свойственны преимущественно тому или иному возрасту» [1, с. 21]. Однако, они считают, что возраст не является причиной преступлений, одновременно возраст связан с характером преступления и криминальной активностью человека.

Также, возраст является показателем совокупности социальных изменений личности с учетом прошедшего времени. Помимо физиологических изменений с возрастом человек приобретает различные социальные качества: привычки, характер, способность действовать в той или иной ситуации.

С возрастом изменяются потребности, жизненные приоритеты, цели, круг интересов, привычки, политические, религиозные и социальные взгляды, появляется определенный жизненный опыт, способность совершить те или иные поступки, в том числе и преступления.

Необходимость возрастной периодизации для лиц, совершивших преступления вызвана, в первую очередь неэффективной системой исполнения наказания. Об этом свидетельствуют данные об увеличении уровня рецидивной преступности. Так, по итогам 2019 года в исправительных колониях содержалось 249,999 лиц, осужденных к лишению свободы второй и более 
раз, что на 10 \% процентов больше чем 10 дет назад. При этом в 20 - 25 лет рецидивист имеет уже две - три судимости, в 25 30 лет человек уже судим четыре раза, после 30 лет всё чаще встречаются личности, судимые 5 и более раз [2].

Исходя из анализа приговоров, мы выявили средний возраст преступника-рецидивиста - 37,3 года. Столь зрелый возраст объясняется истечением определенного времени с момента отбывания наказания за первое преступление до следующего осуждения уже за новое уголовно наказуемое деяние.

Исходя из данных, приведенных данных, следует отметить, что на момент проведения исследования численности рецидивистов, отбывающих наказание исправительных учреждениях, преимущественную часть осужденных, повторно отбывающих наказание в виде лишения свободы, занимают лица в возрастной группе - от 26 до 50 лет (около $87 \%$ ). Лиц в возрасте до 26 лет было всего 12,5 \%.

Но если мы обратим внимания на возраст, когда преступник впервые совершил общественно опасное деяние, то появляются данные не по такому зрелому возрасту. Так каждый второй рецидивист свое первое преступление в возрасте до 18 лет, до 26 лет эта цифра уже возрастает до 90 \%. Это говорит о том, что именно в юном возрасте личность наиболее подвержена внешним негативным факторам, криминальной субкультуре, преступному окружению. При этом, практически все несовершеннолетние осужденные состояли на учете в органах внутренних дел. щаясь к данным Главного управления портала правовой статистики и информационных технологий Генеральной Прокуратуры Российской Федерации, можно отметить, что удельный вес женщин в общем числе выявленных лиц составляет 16,2 \%, за 2019 года [2]. При этом происходит «омоложение» преступности женщин: «растет криминальная активность, снижаются возрастные показатели, расширяется круг совершаемых девушками подростками преступлений, увеличивается их групповая часть, возрастает общественная опасность» [3, с. 140].

Проблема преступности несовершеннолетних женского пола приобретает особую актуальность, что обусловлено как теоретическими исследованиями, так и статистическими показателями, отражающими неуклонный рост женской подростковой преступности [4, с. 25].

Под преступностью несовершеннолетних женщин понимается совокупность преступлений и лиц, их совершивших, в возрасте от 14 до 18 лет. Статистические и иные материалы показывают, что ряд процессов, влияющих на тенденции развития преступности несовершеннолетних, имеет место и в среде младших подростков, не являющихся субъектами преступлений (10-13 лет), а также лиц молодого возраста (18-25 лет).

Обратим внимание на характеристику лиц, содержащихся в воспитательных колониях длянесовершеннолетних (таблица № 1) [5].

В 2019 году число осужденных несовершеннолетних женского пола состави-

Таблица № 1

Лица, содержащиеся в воспитательных колониях для несовершеннолетних c 2014 по 2019 г.

\begin{tabular}{|c|c|c|c|c|c|c|}
\hline & 2014 & 2015 & 2016 & 2017 & 2018 & 2019 \\
\hline Всего осужденных & 1776 & 1683 & 1655 & 1395 & 1310 & 1155 \\
\hline женского пола & 95 & 93 & 119 & 113 & 105 & 95 \\
\hline мужского пола & 1681 & 1590 & 1536 & 1282 & 1205 & 1060 \\
\hline
\end{tabular}

Таким образом, правильней будет говорить о зависимости между началом преступной жизни и последующим криминальным поведением: чем моложе будет человек, когда совершит первое преступления, тем больше вероятность того, что он будет совершать преступления вновь. С возрастом становясь всё более асоциальной либо антисоциальной личностью.

В Российской Федерации в последнее время отмечается тенденция к неуклонному росту женской преступности. Обра- ло 95 тысяч человек, что на 9,5 \% ниже, чем за аналогичный период в 2019 году (105 тысяч). При этом от общего числа осужденных несовершеннолетних девушки составляют 7,8. И что не менее важно, 12 \% осужденных женского пола имели неснятые и непогашенные судимости на момент судебного рассмотрения.

М.В. Прохорова верно отмечает, что «несовершеннолетние осужденные женского пола характеризуются высокой криминогенностью в силу того, что более 50 \% 
отбывают наказание за убийство, умышленное причинение тяжкого вреда здоровью, изнасилование, разбой и грабеж» [3, C. 139].

Если мы обратимся кстатистики за 2019 г, то большинство преступлений девушки подростки совершили по ст. 162 УК РФ - 18 тысяч, на втором месте это ст. 111 УК РФ и ст. 105 УК РФ - по 9 тысяч, и по 6 тысяч по ст. 158 УК РФ [5].

Заметим, что объект преступлений, которые наиболее часто совершаются несовершеннолетними девушками, и за которое уже назначено реальное наказание в виде лишения свободы - жизнь и здоровье человека.

Проанализировав же судебную практику, можно сделать вывод, что ещё до первого осуждения, несовершеннолетние лица женского пола успевают совершать несколько преступлений. Причины неоднократного совершения преступлений несовершеннолетними лицами женского пола, чья преступная деятельность оставалась без надлежащего реагирования со стороны государства и общества в целом, формируется вокруг такого криминоген- ного фактора, как безнаказанность.

Таким образом, вышесказанное, заставляет с осторожностью относиться к данным официальной статистики, увеличением доли несовершеннолетних преступников женского пола, до первого осуждения, несовершеннолетние лица женского пола успевают совершать несколько преступлений, не реагирование государственных органов. Все эти фактысвязанны с высоким уровнем латентности рецидивной женской подростковой преступности.

Для того чтобы показатели в различных структурных компонентах несовершенной преступности не росли вверх, следует постоянно совершенствовать формы и способы работы правоохранительных органов, обеспечивать подобающим образом их приоритетное кадровое пополнение и материально-техническое снабжение. Большую роль уделять мерам общей и индивидуальной профилактики, применяемым правоохранительными органами в целях устранения обстоятельств и условий, способствующих преступлениям несовершеннолетних.

\section{Литература}

1. Казак Б.Б., Ушатиков А.И. Пенитенциарная психология (психология тюремной среды): Учебное пособие. Рязань, 1998. 562 с.

2. Состояние преступности в России за январь-июль 2019 года [Электронный ресурс]: Главное управление правовой статистики и информационных технологий Генеральной Прокуратуры Российской Федерации// URL: http://crimestat. ru/analytics (дата обращения 17.05.2020)

3. Прокопенко, Е.А.. Криминологические взаимосвязи преступности несовершеннолетних женского пола // Вестник Московского университета МВД России. 2010. №12. C. $139-143$.

4. Грибанов Е. В. Преступность несовершеннолетних в контексте культуральной криминологии: монография / под науч. ред. А. В. Симоненко. Краснодар, 2017. 201 c.

5. Характеристика лиц, содержащихся в воспитательных колониях для несовершеннолетних [Электронный ресурс]: официальный сайт ФСИН России// URL:http://xn--h1akkl.xn--p1ai/structure/inspector/iao/statistika/Xar-ka\%20v\%20

\section{References}

1.Kazak B.B., Ushatikov A.I. Penitentsiapnaya psixologiya (psixologiya tyupemnoy spedy): Uchebnoye posobie. Pyazan', 1998. 562 s.

2.Sostoyaniye prestupnosti v Rossii za yanvar'-iyul' 2019 goda [Elektronnyy resurs]: Glavnoye upravleniye pravovoy statistiki i informatsionnykh tekhnologiy General'noy Prokuratury Rossiyskoy Federatsii// URL: http://crimestat.ru/analytics (data obrashcheniya 17.05.2020)

3.Prokopenko, Ye.A.. Kriminologicheskiye vzaimosvyazi prestupnosti nesovershennoletnikh zhenskogo pola // Vestnik Moskovskogo universiteta MVD Rossii. 2010. №12. S. 139-143.

4.Gribanov Ye. V. Prestupnost' nesovershennoletnikh v kontekste kul'tural'noy kriminologii: monografiya / pod nauch. red. A. V. Simonenko. Krasnodar, 2017. $201 \mathrm{~s}$. 5. Kharakteristika lits, soderzhashchikhsya $v$ vospitatel'nykh koloniyakh dlya nesovershennoletnikh [Elektronnyy resurs]: ofitsial'nyy sayt FSIN Rossii// URL:http://xn--h1akkl.xn--p1ai/structure/inspector/iao/statistika/Xar-ka\%20v\%20 (dataobrashcheniya 17.05.2020). 
КОВАЛЕВА Надежда Сергеева, аспирантка кафедры уголовного права и криминологии Челябинского государственного университета. 454001, г. Челябинск, ул. Братьев Кашириных, 129. E-mail: nmichunova@mail.ru

KOVALEVA Nadezhda, Postgraduate Student, Department of Criminal Law and Criminology, Chelyabinsk State University. 454001, Chelyabinsk, st. Kashirin brothers, 129. E-mail: nmichunova@mail.ru 